\title{
Differential Phosphorylation of Azidothymidine, Dideoxycytidine, and Dideoxyinosine in Resting and Activated Peripheral Blood Mononuclear Cells
}

\author{
Wen-Yi Gao, ${ }^{\star \star}$ Takuma Shirasaka, ${ }^{\ddagger}$ David G. Johns, ${ }^{*}$ Samuel Broder, ${ }^{5}$ and Hiroaki Mitsuya ${ }^{\star}$ \\ * Laboratory of Medicinal Chemistry and ${ }^{\ddagger}$ Medicine Branch, ${ }^{\S}$ National Cancer Institute, Bethesda, Maryland 20892
}

\begin{abstract}
The antiviral activity of azidothymidine (AZT), dideoxycytidine (ddC), and dideoxyinosine (ddI) against HIV-1 was comparatively evaluated in PHA-stimulated PBM. The mean drug concentrations which yielded $50 \%$ p24 Gag negative cultures were substantially different: $0.06,0.2$, and $6 \mu \mathrm{M}$ for $\mathrm{AZT}$, ddC, and ddI, respectively. We found that AZT was preferentially phosphorylated to its triphosphate (TP) form in PHA-PBM rather than unstimulated, resting PBM (R-PBM), producing 10- to 17-fold higher ratios of AZTTP/dTTP in PHA-PBM than in R-PBM. The phosphorylation of $\mathrm{ddC}$ and ddI to their TP forms was, however, much less efficient in PHA-PBM, resulting in $\sim 5$-fold and $\sim$ 15-fold lower ratios of ddCTP/ dCTP and ddATP/dATP, respectively, in PHA-PBM than in R-PBM. The comparative order of PHA-induced increase in cellular enzyme activities examined was: thymidine kinase $>$ uridine kinase $>$ deoxycytidine kinase $>$ adenosine kinase $>$ 5'-nucleotidase.

We conclude that AZT, ddC, and ddI exert disproportionate antiviral effects depending on the activation state of the target cells, i.e., ddI and ddC exert antiviral activity more favorably in resting cells than in activated cells, while AZT preferentially protects activated cells against HIV infection. Considering that HIV-1 proviral DNA synthesis in resting lymphocytes is reportedly initiated at levels comparable with those of activated lymphocytes, the current data should have practical relevance in the design of anti-HIV chemotherapy, particularly combination chemotherapy. (J. Clin. Invest. 1993.91:2326-2333.) Key words: azidothymidine • dideoxycytidine • dideoxyinosine • antiviral drugs $\bullet$ phosphorylation
\end{abstract}

\section{Introduction}

Dividing, long-term cultured cell lines and mitogen-stimulated human PBM have been used frequently as target cells for the study of antiviral activity of various drugs against HIV-1 (1-

Address correspondence to Dr. Hiroaki Mitsuya, The Experimental Retrovirology Section, Medicine Branch, National Cancer Institute, Bethesda, MD 20892.

Received for publication 23 October 1992 and in revised form 13 January 1993.

The Journal of Clinical Investigation, Inc.

Volume 91, May 1993, 2326-2333
6). PHA-stimulated PBM (PHA-PBM) ${ }^{1}$ may serve as one of the most suitable target cells for antiviral testing, since they may provide a milieu close to the physiological condition. However, it is as yet poorly understood whether the sensitivity of HIV-1 to drugs as assessed in vitro in PHA-PBM reflects the virus-drug interactions in patients with HIV-1 infection.

In general, HIV-1 replicates more abundantly and rapidly in dividing, activated cells than in nondividing resting cells. HIV-1 proviral DNA synthesis in nondividing, resting cells, however, is initiated as efficiently as in activated cells, although the production of progeny virion requires further activation (7-9). PHA, a T cell mitogen, has been used to activate PBM to ensure productive $\mathrm{HIV}-1$ replication in various in vitro drug assays (1-6). PHA stimulation is known to activate cellular enzymes that are directly involved in cellular DNA synthesis, to increase the size of intracellular dNTP pools, and to initiate cellular DNA synthesis (10). Among these cellular enzymes, nucleoside kinases are responsible for the 5'-phosphorylation of natural ribonucleosides and 2'-deoxynucleosides. These nucleoside kinases are also responsible for the anabolic phosphorylation of $2^{\prime}, 3^{\prime}$-dideoxynucleoside analogues (ddN) such as 3'-azido-2',3'-dideoxythymidine (AZT or zidovudine), 2',3'dideoxycytidine (ddC or zalcitabine), and 2',3'-dideoxyinosine (ddI or didanosine) to their corresponding 5'-triphosphates (11-14). It is now known that different ddN require different cellular enzymes for their anabolic phosphorylation. For example, the initial step of AZT phosphorylation is catalyzed by thymidine kinase (11), while that of $\mathrm{ddC}$ is by deoxycytidine kinase (12). The initial step of phosphorylation of ddI is known to be catalyzed by cytosolic 5'-nucleotidase (14). After these initial 5'-monophosphorylation steps, AZT, ddC, and ddI are ultimately 5'-triphosphorylated by other cellular enzymes (15). Thus, each of these ddNs should be considered as different agents. Moreover, if cellular activation alters the expression and / or functions of cellular enzymes, PHA stimulation may also cause alterations of the antiviral activity of ddN against HIV-1. In this regard, it remains unclear whether antiviral activities determined in vitro by using PHA-PBM as target cells reflect the antiviral activity of given compounds in vivo.

1. Abbreviations used in this paper: ARC, AIDS-related complex; AZT, 3'-azido-2',3'-dideoxythymidine; $\mathrm{CN}_{50}$, drug concentration that yielded $50 \%$ p24 Gag protein-negative wells. ddA, 2',3'-dideoxyadenosine; ddC, 2',3'-dideoxycytidine; ddI, 2',3'-dideoxyinosine; ddN, 2', 3'dideoxynucleosides; PHA-PBM, PHA-stimulated PBM; R-PBM, resting PBM. 
In this paper, we describe our finding that AZT is extremely potent against clinical HIV-1 isolates in comparison to ddI when assessed in PHA-PBM on the basis of molarity. The antiviral activity of AZT was $\sim 100$-fold more potent than that of ddI. These findings pose a clear contrast with the currently recommended daily doses of AZT and ddI, which are both $\sim 500 \mathrm{mg}$ (16-20), producing peak plasma concentrations of both AZT and ddI of $\sim 2-5 \mu \mathrm{M}(20,21)$ and roughly comparable antiviral activity in patients, although precise regimens for both drugs are still under study. These differences between in vitro and in vivo antiviral activity of AZT and ddI could be due to different pharmacokinetics (e.g., intracellular half-life) (17, 20,21). However, it is also possible that PHA-stimulation may cause substantial changes in the intracellular metabolism of $\mathrm{ddN}$, therefore, the in vitro antiviral data generated by using PHA-PBM may not necessarily reflect the ddN-HIV interactions in patients. To address these issues, we examined several biochemical features of AZT, ddC, and ddI in both resting and activated PBM.

\section{Methods}

Nucleosides. AZT was obtained from Sigma Chemical Co. (St. Louis, MO). ddC, ddI, and ddA were supplied by Dr. Karl Flora, Developmental Therapeutics Program, National Cancer Institute. $\left[{ }^{3} \mathrm{H}\right]$ AZT $(14 \mathrm{Ci} / \mathrm{mmol}),\left[{ }^{3} \mathrm{H}\right] \operatorname{ddC}(6 \mathrm{Ci} / \mathrm{mmol})$, and $\left[{ }^{3} \mathrm{H}\right] \operatorname{ddA}(29 \mathrm{Ci} / \mathrm{mmol}$; sugar labeled) were obtained from Moravek Biochemicals, Inc. (Brea, CA). $\left[{ }^{3} \mathrm{H}\right] \mathrm{ddI}$ was prepared by enzymatic deamination of $\left[{ }^{3} \mathrm{H}\right] \mathrm{ddA}$ using calf intestinal adenosine deaminase (adenosine aminohydrolase, EC 3.5.4.4.; Sigma). All other nucleoside/nucleotide standards and PHA were purchased from Sigma Chemical Co.

Isolation of clinical HIV-1 strains. All HIV-1 strains were isolated from 12 patients with AIDS or AIDS-related complex (ARC) before they received antiviral therapy at the National Cancer Institute. Four patients had a history of AZT monotherapy and had developed HIV-1 variants less susceptible to AZT (6), and the data of the AZT sensitivity of these patients' strains were not included.

To isolate HIV-1 strains, PBM $\left(1 \sim 2 \times 10^{6}\right)$ from patients were cocultured with PHA $(10 \mu \mathrm{g} / \mathrm{ml}$, Sigma)-activated PBM $(1 \sim 2$ $\times 10^{6}$ ) from HIV-1 seronegative volunteers in 24-well microtiter culture plates (Costar Corp., Cambridge, MA) in $2 \mathrm{ml}$ of culture media (RPMI 1640 medium supplemented with $15 \%$ heat-inactivated fetal calf serum, recombinant IL-2, $10 \mathrm{U} / \mathrm{ml}$; Amgen Biologicals, Thousand Oaks, CA, $4 \mathrm{mM} \mathrm{L-glutamine,} 50 \mathrm{U} / \mathrm{ml}$ of penicillin, and $50 \mu \mathrm{g} / \mathrm{ml}$ of streptomycin). When the level of $\mathrm{p} 24 \mathrm{Gag}$ protein in the culture supernatant reached $\geq 10 \mathrm{ng} / \mathrm{ml}$ within $10 \mathrm{~d}$ as assessed by $\mathrm{p} 24 \mathrm{Gag}$ protein radioimmunoassay (DuPont, Boston, MA), the supernatant was collected as a source of infectious virions and stored at $-70^{\circ} \mathrm{C}$, as described previously (6). The success rate of isolating HIV-1 from patients' PBM was $\sim 90 \%$ in this study.

Determination of sensitivity of clinical HIV-1 strains against 2',3'dideoxynucleosides. Each HIV-1-containing supernatant was titrated for $50 \%$ tissue culture infectious dose $\left(\mathrm{TCID}_{50}\right)$ using PHA-PBM and the p24 Gag protein radioimmunoassay, as previously described (6). Titration was performed in eight replicates. To determine the drug sensitivity of each HIV-1 strain, $5 \times 10^{5}$ PHA-PBM, which had been in culture for 2-3 d in IL-2-containing culture medium after stimulation with PHA $(10 \mu \mathrm{g} / \mathrm{ml})$, were exposed to a $20 \mathrm{TCID}_{s 0}$ dose of each virus isolate and cultured in the presence or absence of various concentrations of AZT, ddC, or ddI. The sensitivity of a given HIV-1 strain against a drug was defined as the drug concentration that yielded $50 \%$ p24 Gag protein-negative wells $\left(\mathrm{CN}_{50}\right)(6)$. When the concentration of p24 Gag protein was below the detectable level assessed by RIA assay kit (DuPont), that culture was defined as a negative well. All cultures were performed in quadruplicate in 24-well microtiter culture plates.

Metabolism studies. Freshly isolated PBM were stimulated with PHA $(10 \mu \mathrm{g} / \mathrm{ml})$ and cultured for $72 \mathrm{~h}$ in IL-2-containing culture medium (PHA-PBM). Freshly isolated, nondividing resting PBMC (R-PBM) and PHA-PBM were pulse labeled with $10 \mu \mathrm{M}\left[{ }^{3} \mathrm{H}\right]-$ dideoxynucleosides ( $1 \mathrm{Ci} / \mathrm{mmol}$ ) for $12 \mathrm{~h}$ in IL-2-containing culture medium. Cells were then centrifuged and washed three times with cold PBS. After centrifugation, the cell pellets were subjected to extraction with $60 \%$ methanol. The extracts were then heated for 2 min at $95^{\circ} \mathrm{C}$ and analyzed by chromatography on an ion exchange column (Partisil 10-SAX; Whatman Inc., Hillsboro, NJ) as previously described $(22,23)$.

Determination of intracellular dNTP pools. To quantitate deoxyribonucleoside triphosphates (dNTPs), an enzymatic assay using DNA polymerase and synthetic oligonucleotides as templates was employed as previously described by Sherman and Fyfe (24). In this assay, one dNTP present in excess is radiolabeled and the amount of radioactivity incorporated into DNA is proportional to the dNTP to be quantified. Briefly, PBM preparations were incubated with or without ddN for 72 h. After centrifugation, the cell pellets were washed three times with cold PBS and were subjected to extraction with $60 \%$ methanol. The extracts were then heated for $2 \mathrm{~min}$ at $95^{\circ} \mathrm{C}$.

The reaction mixture contained $0.05 \mathrm{U}$ Sequenase 2.0 (United States Biochemical Corp.; Cleveland, $\mathrm{OH}$ ), $50 \mathrm{mM}$ Tris- $\mathrm{HCl}$ ( $\mathrm{pH} 7.5$ ), $10 \mathrm{mM} \mathrm{MgCl}_{2}, 5 \mathrm{mM}$ dithiothreitol, $0.5 \mathrm{mg} / \mathrm{ml} \mathrm{BSA}, 0.25 \mathrm{mM}$ template primer, $2.5 \mathrm{mM}\left[{ }^{3} \mathrm{H}\right] \mathrm{dATP}(15 \mathrm{Ci} / \mathrm{mmol}$, for dCTP, dGTP, and dTTP determinations $)$ or $2.5 \mathrm{mM}\left[{ }^{3} \mathrm{H}\right] \mathrm{dTTP}(15 \mathrm{Ci} / \mathrm{mmol}$, for dATP determination), to which known amounts of dNTP standard samples or $5 \mu \mathrm{l}$ of cell extract were added. The total assay volume was $50 \mu \mathrm{l}$. Reactions were carried out at $26^{\circ} \mathrm{C}$, followed by placing each reaction mixture onto a filter (DE81; Whatman Inc., Clifton, $\mathrm{NJ}$ ). The filters were dried, extensively washed with $5 \% \mathrm{Na}_{2} \mathrm{HPO}_{4}$, once with distilled water, and then with $95 \%$ ethanol, and dried. The radioactivity on the filters was then counted in a liquid scintillation counter. The radioactivity (disintegrations per minute) was plotted against the amounts of dNTPs. The dNTP amounts in test samples were determined from these standard curves. In determining dNTP amounts in samples extracted from ddN-treated cells, an extract from cells cultured in the absence of ddN was mixed with an extract from ddN-treated cells in various ratios and the mixtures were subjected to the polymerase assay. From thus obtained linear curves for correction, the reduction by ddNTP was determined and the dNTP amounts were adjusted to represent the values otherwise obtained in the absence of ddNTP.

Nucleoside kinase and 5'-nucleotidase assays. Resting PBM ( RPBM) and PHA-PBM $\left(1 \times 10^{8}\right)$ were incubated for $12 \mathrm{~h}$ at $37^{\circ} \mathrm{C}$, and activities of nucleoside kinases and cytosolic 5 '-nucleotidase of the cell lysates were determined. Briefly, the cell pellet of each PBM preparation was washed three times with cold PBS and disrupted by one cycle of freezing-thawing followed by sonication in $500 \mu$ l of extraction buffer ( $300 \mathrm{mM} \mathrm{KCl} ; 50 \mathrm{mM}$ Tris-HCl, pH 7.5; $4 \mathrm{mM} \mathrm{MgCl}_{2} ; 2 \mathrm{mM}$ dithiothreitol; $1 \mathrm{mM}$ PMSF; and 20\% glycerol). After centrifugation, the supernatants (protein extracts) were examined for activities of various cellular kinases as well as cytosolic 5'-nucleotidase. The observed enzymatic activities were normalized to the unit of enzymatic activity $/ \mathrm{mg}$ of protein. All enzyme assays were performed at $37^{\circ} \mathrm{C}$ and the activity was determined in the linear portion of the activity curve as described previously (25). The reaction mixtures for determination of thymidine kinase, deoxycytidine kinase, adenosine kinase, and uridine kinase contained $90 \mu \mathrm{M}{ }^{14} \mathrm{C}$-labeled thymidine (dT), 2'-deoxycytidine (dC), adenosine, and uridine, respectively, and $3 \mathrm{mM}$ phosphocreatine, $1 \mathrm{U}$ of creatine phosphokinase, $2 \mathrm{mM} \mathrm{MgCl} \mathrm{m}_{2}-\mathrm{ATP}, 0.5 \mathrm{mg} / \mathrm{ml}$ $\mathrm{BSA}$, and $100 \mathrm{mM}$ Tris- $\mathrm{HCl}, \mathrm{pH} 7.5$. The reaction mixture for determination of cytosolic 5'-nucleotidase activity contained $2.5 \mu \mathrm{M}\left[{ }^{3} \mathrm{H}\right]-$ inosine ( $3.2 \mathrm{mCi} / \mathrm{mmol}$ ); $100 \mathrm{mM}$ Tris- $\mathrm{HCl}, \mathrm{pH} 7.5 ; 50 \mathrm{mM} \mathrm{MgCl}$; $500 \mathrm{mM} \mathrm{KCl} ; 5 \mathrm{mM} \mathrm{IMP} ; 4 \mathrm{mM}$ DTT; and $5 \mathrm{mM}$ ATP. 


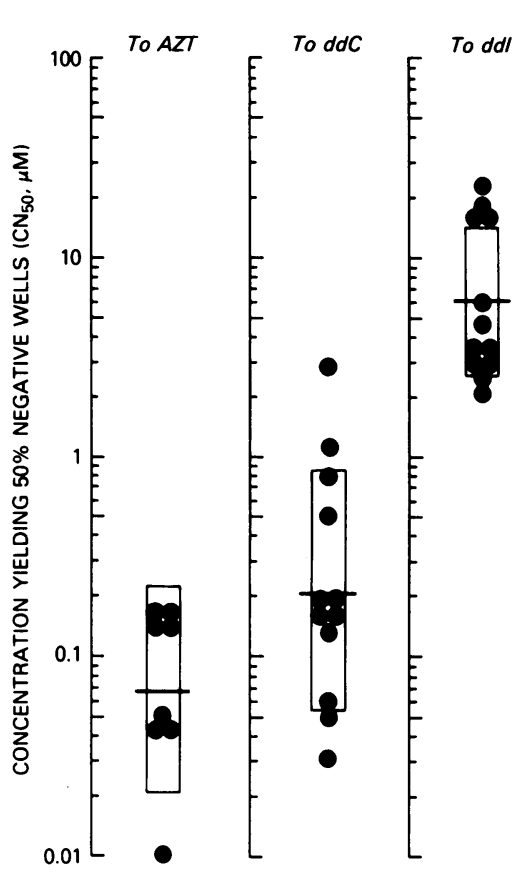

Figure 1. Comparative in vitro sensitivity of primary HIV-1 isolates against AZT, ddC, and ddI. The drug sensitivity of each primary isolate is expressed as $\mathrm{CN}_{50}$. Geometric means of $\mathrm{CN}_{50}$ values with one standard deviation as a range were $0.06 \mu \mathrm{M}$ $(0.02-0.22), 0.2 \mu \mathrm{M}$ (0.05-0.8), and $6 \mu \mathrm{M}$ (3-14) for AZT, ddC, and ddI, respectively. The $\mathrm{CN}_{50}$ values for ddI are significantly higher than those for AZT ( $P$ $=0.0004)$ and those for $\operatorname{ddC}(P<0.0001)$ as assessed by Wilcoxon's rank sum test. The $\mathrm{CN}_{50}$ values for AZT do not differ from those for $\operatorname{ddC}(P=0.22)$.

\section{Results}

Anti-HIV-I activities of AZT, ddI, and ddC in PHA-activated $P B M C$. We first evaluated the antiviral activity of AZT, ddC, and ddI against primary HIV-1 strains isolated from 12 different patients with AIDS or AIDS-related complex in an assay system using PHA-PBM as target cells and p24 Gag protein production as an endpoint. We found that AZT was extremely potent against the virus as compared to $\mathrm{ddC}$ and $\mathrm{ddI}$ on the basis of molarity (Fig. 1). In the present study, PBM that had been cultured for 2-3 d after PHA stimulation were exposed to each of primary HIV-1 strains and cultured in the presence or absence of various concentrations of AZT, ddC, or ddI. The mean $\mathrm{CN}_{50}$ were $0.06 \mu \mathrm{M}$ (1 SD: range, $0.02-0.22$ ), $0.2 \mu \mathrm{M}$ (0.05-0.8), and $6 \mu \mathrm{M} \mathrm{(3-14)} \mathrm{for} \mathrm{AZT,} \mathrm{ddC,} \mathrm{and} \mathrm{ddI,} \mathrm{respec-}$ tively. The $\mathrm{CN}_{50}$ values of AZT and ddC were significantly lower than those of ddI ( $P=0.0004$ for AZT vs ddI and $P$ $<0.0001$ for ddC vs ddI) as assessed by Wilcoxon's rank sum test. The $\mathrm{CN}_{50}$ values for AZT did not differ from those for ddC $(P=0.22)$.

Phosphorylation of dideoxynucleosides in $R-P B M$ and PHA-PBM. The effects of PHA stimulation on anabolic phosphorylation of radiolabeled AZT, ddC, ddI, and ddA in PBM were examined. R-PBM and PHA-PBM were exposed to each of the four radiolabeled $2^{\prime}, 3^{\prime}$-dideoxynucleoside analogues ( 10 $\mu \mathrm{M})$, and the levels of intracellular 5'-phosphates were quantified by using HPLC. Fig. 2 shows representative profiles of intracellular concentrations of metabolites for each dideoxynucleoside. Levels of intracellular AZT-5'-mono, di-, and triphosphates (MP, DP, and TP) were 110-, 30-, and 40-fold higher, respectively, in PHA-PBM as compared with those in R-PBM (Fig. $2 \mathrm{~A}$ ). In contrast, intracellular levels of ddCMP, -DP, and -TP were 10-, 10-, and 4-fold higher, respectively, in PHAPBM (Fig. $2 B$ ). When the cells were incubated with ddI or ddA, both dideoxypurine nucleosides were poorly phosphorylated as compared to AZT. Moreover, there was only a less

than twofold increase in the formation of ddATP in PHA-PBM as compared to that in R-PBM (Fig. $2 C$ and $D$ ).

Kinetic study showed that the increase in the cellular AZTTP pool in PHA-PBM was significantly higher and occurred much sooner than in R-PBM (Fig. $3 A$ ). The concentration of AZTTP reached a plateau by 6 and $12 \mathrm{~h}$ of culture in R-PBM and PHA-PBM, respectively. In contrast, intracellular ddCTP levels continue to increase throughout the 24-h period of time in both R-PBM and PHA-PBM, while its absolute concentrations were substantially lower compared to that of AZTTP (Fig. $3 A$ ). The formation of ddATP was found to be much poorer, and there was virtually no difference in its intracellular level between R-PBM and PHA-PBM for up to $12 \mathrm{~h}$ in culture (Fig. $3 \mathrm{~A}$ ). Moreover, the level of ddATP was lower than that of AZTTP or ddCTP in corresponding PBM populations throughout the 24-h culture interval. A quantitative study of each nucleotide form of AZT revealed a profound increase in AZTMP level in PHA-PBM as compared to that in R-PBM (Fig. $3 B$ ), which confirmed previous findings by Furman et al. (11) and others (26).

Determination of ratios of 2',3'-dideoxynucleoside-5'-triphosphates $/ 2$ '-deoxynucleoside-5'-triphosphates. The ratio of $2^{\prime}, 3^{\prime}$-dideoxynucleoside-5'-triphosphate over 2'-deoxynucleoside-5'-triphosphate (ddNTP/dNTP) is one of the most important determinants of antiviral activity of ddN against HIV1. We, therefore, evaluated the intracellular pool sizes of dTTP, dCTP, and dATP by employing an enzymatic assay using synthetic oligonucleotides as template-primers (24) and determined the ratios of intracellular AZTTP/dTTP, ddCTP/dCTP, and ddATP/dATP.

As shown in Table I, when PBM from donor A were examined, the intracellular AZTTP levels were 0.03 and $5.29 \mathrm{pmol} /$ $10^{6}$ cells and those of dTTP were 0.48 and $6.09 \mathrm{pmol} / 10^{6}$ cells in R-PBM and PHA-PBM, respectively (Table I). The resulting AZTTP/dTTP ratio showed a substantial increase from 0.06 to 0.87 (14.5-fold increase). By contrast, the ratios of ddCTP/dCTP and ddATP/dATP decreased from 2.11 to 0.28 (7.5-fold decrease) and from 0.44 to 0.03 ( 14.7 -fold decrease) when determined in R-PBM and PHA-PBM from the same donor $\mathrm{A}$ exposed to $\left[{ }^{3} \mathrm{H}\right] \mathrm{ddC}$ and $\left[{ }^{3} \mathrm{H}\right] \mathrm{ddI}$, respectively. As expected, when the cells were cultured with ddA, the ratio of ddATP/dATP also showed a substantial decrease from 1.37 to 0.11 (12.5-fold decrease), which was very close to the decrease seen with ddI ( Table I). Changes in the ddNTP/dNTP ratios were comparable when two additional pairs of R-PBM and PHA-PBM isolated from donors $B$ and $C$ were used (Table I).

Effects of AZT, ddC, ddI, and ddA on the cellular dNTP pools were also determined. As shown in Table II, the levels of dNTPs were dramatically increased by PHA stimulation. In both R-PBM and PHA-PBM, the levels of dGTP and AATP were lower than those of dCTP and dTTP. After 72-h exposure of the cells to $10 \mu \mathrm{M} \mathrm{AZT}$, ddI, or ddA, cellular dNTP pools did not show significant changes, whereas the exposure to ddC decreased dCTP levels from 1.15 to 0.21 and 4.24 to $1.87 \mathrm{pmol}$ per $10^{6}$ of R-PBM and PHA-PBM, respectively (Table II).

PHA-induced changes in cellular phosphorylating enzymes. To define the biochemical basis of the observed differential phosphorylation profiles of deoxynucleosides and dideoxynucleosides, we examined the activities of cellular enzymes that mediate phosphorylation of nucleosides and dideoxynucleosides in R-PBM and PHA-PBM. We found that the activity of 


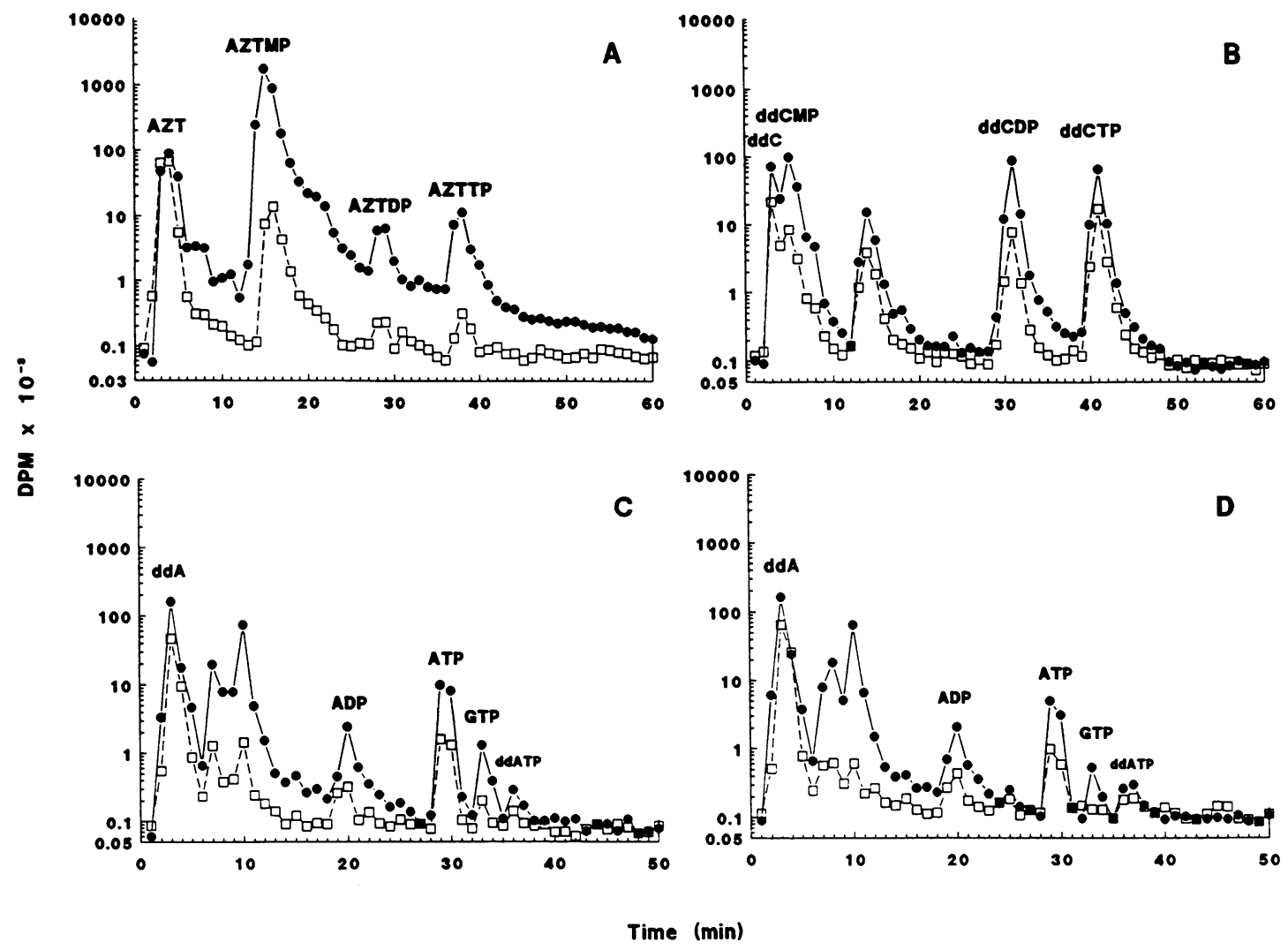

Figure 2. HPLC elution profile of extracts of resting PBM and PHA-PBM incubated with radiolabeled AZT, ddC, ddI, or ddA. Resting PBM and PHA-PBM from one healthy volunteer were incubated with $10 \mu \mathrm{M}\left[{ }^{3} \mathrm{H}\right] \mathrm{AZT}(A),\left[{ }^{3} \mathrm{H}\right] \mathrm{ddC}(B),\left[{ }^{3} \mathrm{H}\right] \mathrm{ddI}(C)$, or $\left[{ }^{3} \mathrm{H}\right] \mathrm{ddA}(D)$ for $12 \mathrm{~h}$. Cellular nucleoside metabolites were extracted with $60 \%$ methanol and analyzed by HPLC as described in Methods. 1-min fractions were collected, and data are expressed as dpm $/ 10^{6}$ cells. Radioactive nucleoside metabolites extracted from resting PBM (open squares) and PHA-PBM (closed circles) are shown.

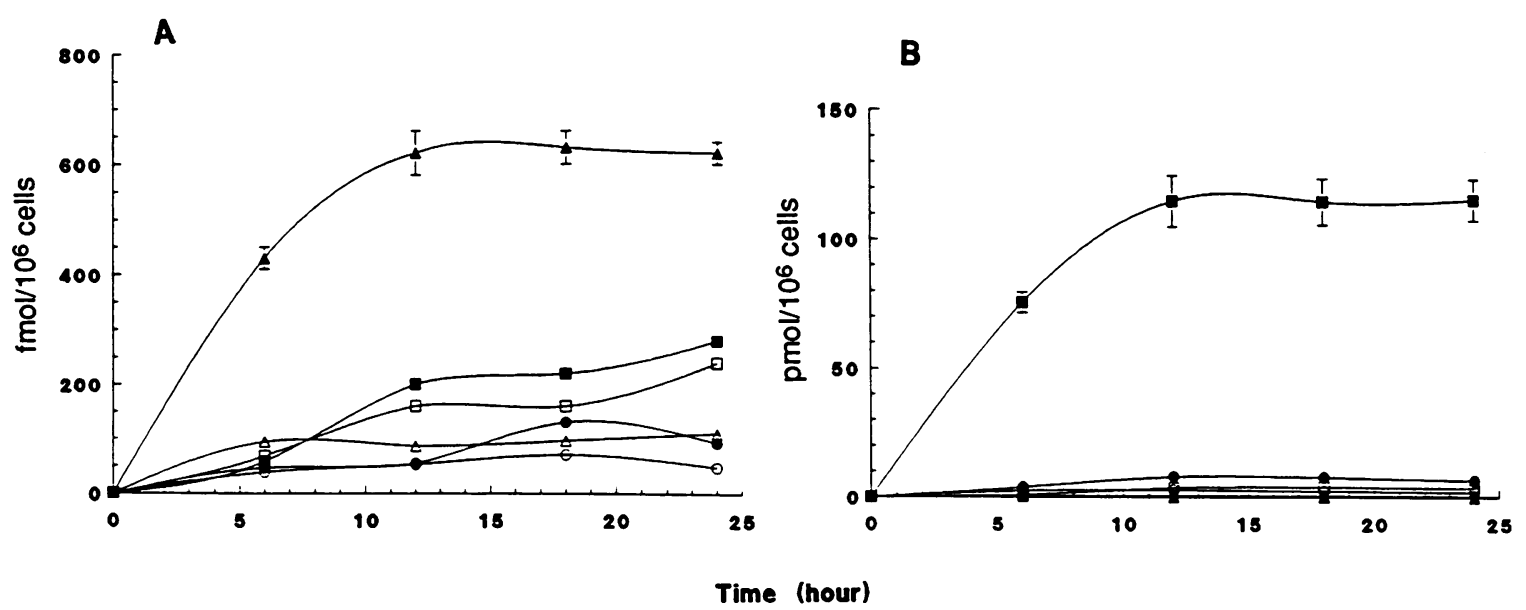

Figure 3. Time-dependent changes in intracellular concentrations of metabolites of AZT, ddC, and ddI in resting PBM and PHA-PBM. ( $A$ ) Concentrations of AZTTP, ddCTP, and ddATP. Resting PBM and PHA-PBM were incubated with [ $\left.{ }^{3} \mathrm{H}\right] \mathrm{AZT},\left[{ }^{3} \mathrm{H}\right] \mathrm{ddC}$, or $\left[{ }^{3} \mathrm{H}\right] \mathrm{ddI}$ for various periods of time and nucleoside metabolites were extracted with $60 \%$ methanol and analyzed by HPLC. The amounts of AZTTP (open and closed triangles), ddCTP (open and closed squares), and ddATP (open and closed circles) are expressed as fmol/106 cells in resting PBM and PHA-PBM, respectively. $(B)$ Time-dependent changes in intracellular concentrations of AZT metabolites ( $\mathrm{pmol} / 10^{6} \mathrm{cells}$ ). AZT (open and closed circles), AZTMP (open and closed squares), AZTDP (open and closed triangles), and AZTTP (open and closed inverted triangles), in resting PBM and PHA-PBM, respectively. 
Table I. Dideoxynucleotides and Deoxynucleotides in Resting and PHA-stimulated Peripheral Blood Mononuclear Cells

\begin{tabular}{|c|c|c|c|c|c|c|c|}
\hline \multirow[b]{2}{*}{ Nucleosides } & \multirow[b]{2}{*}{ Nucleotides } & \multicolumn{2}{|c|}{ Donor A } & \multicolumn{2}{|c|}{ Donor B } & \multicolumn{2}{|c|}{ Donor C } \\
\hline & & R-PBM & PHA-PBM & R-PBM & PHA-PBM & R-PBM & PHA-PBM \\
\hline \multirow[t]{3}{*}{ AZT $(10 \mu \mathrm{M})$} & AZTTP & $0.03 \pm 0.01^{*}$ & $5.29 \pm 0.50$ & $0.02 \pm 0.01$ & $3.64 \pm 0.36$ & $0.02 \pm 0.01$ & $3.52 \pm 0.30$ \\
\hline & dTTP & $0.48 \pm 0.05$ & $6.09 \pm 0.56$ & $0.38 \pm 0.01$ & $7.29 \pm 0.26$ & $0.58 \pm 0.02$ & $7.00 \pm 0.45$ \\
\hline & AZTTP/dTTP & 0.06 & 0.87 & 0.05 & 0.50 & 0.03 & 0.50 \\
\hline \multirow[t]{3}{*}{$\operatorname{ddC}(10 \mu \mathrm{M})$} & ddCTP & $0.36 \pm 0.04$ & $0.74 \pm 0.09$ & $0.45 \pm 0.04$ & $0.83 \pm 0.08$ & $0.60 \pm 0.06$ & $1.12 \pm 0.11$ \\
\hline & $\mathrm{dCTP}$ & $0.17 \pm 0.02$ & $2.65 \pm 0.11$ & $0.20 \pm 0.01$ & $1.20 \pm 0.08$ & $0.27 \pm 0.01$ & $1.75 \pm 0.02$ \\
\hline & ddCTP/dCTP & 2.11 & 0.28 & 2.25 & 0.69 & 2.22 & 0.64 \\
\hline \multirow[t]{3}{*}{$\mathrm{ddI}(10 \mu \mathrm{M})$} & ddATP & $0.04 \pm 0.01$ & $0.05 \pm 0.01$ & $0.06 \pm 0.01$ & $0.07 \pm 0.01$ & $0.05 \pm 0.01$ & $0.06 \pm 0.01$ \\
\hline & dATP & $0.09 \pm 0.02$ & $1.68 \pm 0.07$ & $0.08 \pm 0.01$ & $1.41 \pm 0.04$ & $0.08 \pm 0.01$ & $1.51 \pm 0.10$ \\
\hline & ddATP/dATP & 0.44 & 0.03 & 0.75 & 0.05 & 0.62 & 0.04 \\
\hline \multirow[t]{3}{*}{$\mathrm{ddA}(10 \mu \mathrm{M})$} & ddATP & $0.11 \pm 0.02$ & $0.18 \pm 0 . / 03$ & $0.07 \pm 0.01$ & $0.08 \pm 0.01$ & $0.10 \pm 0.01$ & $0.10 \pm 0.10$ \\
\hline & dATP & $0.08 \pm 0.02$ & $1.62 \pm 0.01$ & $0.07 \pm 0.01$ & $1.43 \pm 0.08$ & $0.08 \pm 0.01$ & $1.52 \pm 0.08$ \\
\hline & ddATP/dATP & 1.37 & 0.11 & 1.00 & 0.06 & 1.25 & 0.07 \\
\hline
\end{tabular}

R-PBM and PHA-PBM ( $10^{7}$ cells) were exposed to ${ }^{3} \mathrm{H}$-labeled AZT, ddC, ddI, or ddA for $12 \mathrm{~h}$. Cell pellets were washed with cold PBS and extracted with $60 \%$ methanol. Cellular dideoxynucleoside metabolites were quantified by HPLC. Cellular deoxynucleotide pool sizes were determined by enzymatic assay (24). Data represent means \pm 1 SD of triplicate determinations. ${ }^{*}$ pmol $/ 10^{6}$ cells. Variability in this assay system was $<5 \%$ of the values obtained.

thymidine kinase, which is responsible for 5'-monophosphorylation of thymidine and AZT, was significantly higher in PHAPBM than in R-PBM. The difference was by as much as 17 -fold (Fig. 4). The activity of deoxycytidine kinase, which mediates 5'-monophosphorylation of $\mathrm{dC}$ and $\mathrm{ddC}$, was slightly higher (twofold) in PHA-PBM than in R-PBM. In contrast, the activity of cellular adenosine kinase, which is responsible for 5'monophosphorylation of adenosine and is thought to contribute to the ultimate formation of dATP, was substantially high in R-PBM, and upon PHA stimulation there was only a slight increase in that kinase activity (1.2-fold) (Fig. 4). Interestingly, the activity of cytosolic 5'-nucleotidase, which catalyzes 5'-monophosphorylation of ddI (14), had rather a slight decrease in PHA-PBM as compared to that in R-PBM (from 660 to $510 \mathrm{nmol} / \mathrm{h}$ per $\mathrm{mg}$ protein) (Fig. 4). The comparative order of degrees of enzymatic activity increase induced by PHA stimulation was thymidine kinase $>$ uridine kinase $>$ deoxycytidine kinase $>$ adenosine kinase $>5$ '-nucleotidase.

\section{Discussion}

The current study demonstrates that antiretroviral $2^{\prime}, 3^{\prime}$-dideoxynucleoside analogues, AZT, ddC, and ddI, present substantially different profiles in anti-HIV activities and anabolic phosphorylation in PHA-PBM and R-PBM. AZT showed an extremely potent antiviral activity against HIV-1 and was roughly 100 -fold more potent than ddI on the basis of molarity as assessed in PHA-PBM. The geometric mean of $\mathrm{CN}_{50}$ was $0.06 \mu \mathrm{M}$ (range $0.02-0.2 \mu \mathrm{M}$ ) as assessed in PHA-PBM. In contrast, the mean $\mathrm{CN}_{50}$ value of ddI was $6 \mu \mathrm{M}$ (range: $3-14$ $\mu \mathrm{M})$ under the same conditions. In this regard, Perno et al. have reported that, in monocyte/macrophages, the anti-HIV

Table II. Deoxynucleoside Triphosphate Pool Sizes in Peripheral Blood Mononuclear Cells

\begin{tabular}{|c|c|c|c|c|}
\hline \multirow[b]{2}{*}{ Cells } & \multicolumn{4}{|c|}{ Pool size (pmol/10 $0^{6}$ cells) } \\
\hline & dCTP & dTTP & dGTP & dATP \\
\hline R-PBM with no drug & $1.15 \pm 0.36$ & $1.02 \pm 0.31$ & $0.14 \pm 0.02$ & $0.15 \pm 0.02$ \\
\hline R-PBM with AZT & $1.59 \pm 0.78$ & $0.61 \pm 0.26$ & $0.11 \pm 0.04$ & $0.16 \pm 0.04$ \\
\hline R-PBM with ddC & $0.21 \pm 0.06$ & $0.73 \pm 0.43$ & $0.10 \pm 0.06$ & $0.12 \pm 0.04$ \\
\hline R-PBM with ddI & $0.97 \pm 0.35$ & $0.89 \pm 0.21$ & $0.11 \pm 0.03$ & $0.09 \pm 0.01$ \\
\hline R-PBM with ddA & $0.80 \pm 0.10$ & $0.87 \pm 0.22$ & $0.11 \pm 0.02$ & $0.08 \pm 0.02$ \\
\hline PHA-PBM with no drug & $4.24 \pm 0.73$ & $6.18 \pm 1.24$ & $1.49 \pm 0.55$ & $1.92 \pm 0.20$ \\
\hline PHA-PBM with AZT & $5.29 \pm 0.97$ & $6.89 \pm 0.54$ & $1.28 \pm 0.31$ & $2.42 \pm 0.31$ \\
\hline PHA-PBM with ddC & $1.87 \pm 0.73$ & $8.99 \pm 1.50$ & $1.92 \pm 0.88$ & $2.94 \pm 0.61$ \\
\hline PHA-PBM with ddI & $3.60 \pm 0.45$ & $5.47 \pm 0.42$ & $1.10 \pm 0.43$ & $1.53 \pm 0.11$ \\
\hline PHA-PBM with ddA & $4.15 \pm 0.69$ & $5.87 \pm 0.91$ & $1.08 \pm 0.41$ & $1.52 \pm 0.10$ \\
\hline
\end{tabular}

R-PBM and PHA-PBM were exposed to $10 \mu \mathrm{M}$ AZT, ddI, ddA or ddC for $72 \mathrm{~h}$. Cells were extracted and 2'-deoxyribonucleoside-5'-triphosphate levels were determined as described in Methods. Data represent mean values \pm 1 SD of three independent experiments, each of which was performed in triplicate using a different donor's PBM preparations. Variability in this assay system was < $5 \%$ of the values obtained. 

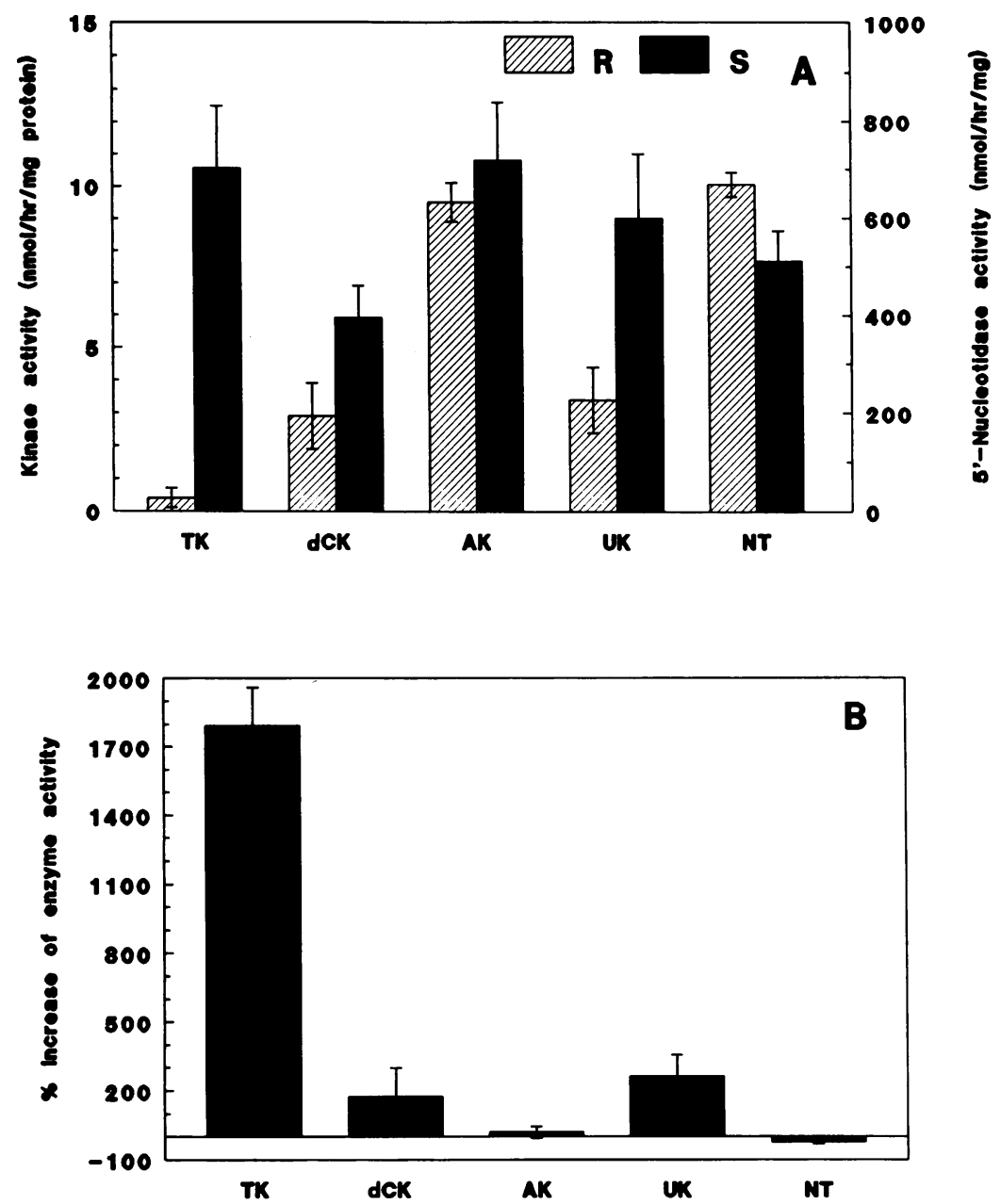

Figure 4. Effects of PHA stimulation on activities of cellular enzymes. Resting PBM and PHA-PBM ( 1 $\times 10^{8}$ ) were incubated for $12 \mathrm{~h}$ at $37^{\circ} \mathrm{C}$ and activities of nucleoside kinases and 5'-nucleotidase in the cell lysates were determined. $1 \mathrm{U}$ of kinase activity is defined as $1 \mathrm{pmol}$ of deoxynucleoside-5'-monophosphates formed per hour. Activities of each kinase in resting PBM (hatched column) and PHA-PBM (closed column) are shown. Data represent the mean \pm SD from two experiments, each of which was performed in triplicate using a different donor's PBM preparations. An additional experiment using another donor's PBM preparations also showed similar profile depicted in this figure. TK, thymidine kinase; dCK, deoxycytidine kinase; $\mathrm{AK}$, adenosine kinase; UK, uridine kinase; NT, 5'-nucleotidase.

activities of AZT and other thymidine analogues, but not that of ddI, are potentiated by the addition of granulocyte macrophage colony-stimulating factor (27), suggesting that the phenomenon is not only with PHA stimulation. The differential antiviral activities of AZT and ddI based on their molarity clearly contrast with the currently recommended doses of AZT and ddI for the therapy of AIDS, which are both $\sim 500 \mathrm{mg}$ and bring about roughly comparable antiviral activities in patients receiving either of the two drugs alone (16-20).

The extremely potent inhibition of HIV-1 replication by AZT in PHA-PBM appears due to the selective, efficient phosphorylation of AZT to its 5'-triphosphate form. Upon PHA stimulation, the increase in AZT-5'-monophosphate was most significant among the AZT metabolites examined (Fig. $2 A$ and Fig. $3 B$ ). This increase correlated with the increased activity of cellular thymidine kinase which was the most sensitive to the PHA-driven induction among the cellular kinases examined (Fig. 4). In contrast, ddI was poorly phosphorylated to its putative active moiety, ddATP, and the activity of cytosolic 5'-nucleotidase, which is responsible for the initial stage of phosphorylation of ddI, was found to be rather decreased in PHAPBM (Fig. 4), while the level of the natural competitor, dATP, had a substantial increase in PHA-PBM (Table I). These results suggest that thymidine kinase plays a critical role in the selective phosphorylation of AZT in PHA-PBM. The relatively poor antiretroviral activity of ddI in PHA-PBM appears to be due to an inefficient conversion of ddI to ddATP coupled with a substantial increase of dATP. In this work, it was also noted that in stimulated PBM, activities of two enzymes, uridine kinase and adenosine kinase, were slightly lower and that of thymidine kinase was higher than such enzymic activities previously reported for certain tumor cells of human or murine origin $(28,29)$, resulting in that activities of the enzymes listed in Fig. 4 were in the same range. This feature seems to be inherent to stimulated human PBM. In fact, Cheng and Traut have observed a similar range of activity of uridine kinase in human PBM and suggested that the activity of uridine kinase is likely to be cell type-specific and dependent on cell growth (30).

Dideoxynucleoside-5'-triphosphates (ddNTP) are known to compete with normal 2 '-deoxynucleoside-5'-triphosphates (dNTP) for binding to reverse transcriptase and / or to be incorporated into the growing retroviral DNA chain to bring about termination of viral DNA synthesis $(31,32)$. Thus, the concentrations of the endogenous competitors, dNTP, influence the antiviral activity of ddN significantly. The ratios of intracellular ddNTP vs dNTP, therefore, are critical for ddN to exert their antiretroviral activity. Our results showed that the ratios of AZTTP/dTTP were more than 10-fold higher in PHA-PBM than in R-PBM, while the ratios of ddATP/dATP were more than 14-fold lower in PHA-PBM than in R-PBM. These data suggest that AZT is more active in protecting activated cells 
against HIV-1 infection than resting lymphocytes, while ddI protects resting cells more favorably than activated lymphocytes.

It is thought that the majority of circulating lymphocytes are nondividing quiescent cells. As in the case of animal retroviruses $(33,34)$, HIV proviral DNA synthesis in quiescent lymphocytes is reportedly initiated as efficiently as in activated lymphocytes $(7,9)$. Buktinsky and his co-workers have recently demonstrated that a large proportion of HIV-1 genome in asymptomatic individuals exists as full length, extrachromosomal DNA, which retains the ability to integrate upon activation of the host cell (8). Thus, we would like to propose that a greater proportion of the antiviral activity of ddI preferentially protects resting cells against the infection by HIV-1 in vivo. In contrast, AZT preferentially protects activated cells against HIV infection in vivo. In fact, we have observed a statistically significant ddI therapy-related decrease in the amount of HIV proviral DNA in freshly isolated unstimulated PBM from patients with AIDS or ARC as assessed by quantitative polymerase chain reaction (35). In contrast, no significant decrease in HIV-1 proviral DNA in unstimulated PBM from patients receiving AZT monotherapy has been detected (36), although when patients were treated with AZT and recombinant IL-2, a significant decline of HIV-1 proviral copies has been identified (37). These data suggest that quiescent lymphocytes were efficiently protected against HIV-1 infection and the viral load (as proviral DNA) in (nondividing) PBM was reduced by ddI therapy but not by AZT monotherapy, although more careful studies are required.

Thus, a regimen of simultaneous administration of AZT and ddI may represent a rational combination therapy. If administered simultaneously, AZT and ddI may provide complementary activity and may exert substantial (possibly synergistic) antiviral effect in vivo. Indeed, studies by Yarchoan et al. indicate that the simultaneous regimen of AZT plus ddI has brought about more significant and long lasting antiviral activity (as assessed by changes in CD4 counts and body weights) to patients with AIDS or ARC than the alternating regimen of AZT for 3 wk and ddI for 3 wk (38).

Our results also suggest that anti-HIV activity determined by using an in vitro assay system, in which only activated or dividing target cells are used, should be carefully interpreted and such data should not be directly extrapolated for clinical application. It is worth noting that multiple target cells including nondividing, quiescent target cells may be considered in evaluating the in vitro antiviral activity and metabolism of any given compounds, in particular, nucleoside analogues.

In PHA-PBM, ddC was less potent than AZT with a mean $\mathrm{CN}_{50}$ value of $0.2 \mu \mathrm{M}$ (Fig. 1). However, to bring about a similar anti-HIV activity, the daily doses of ddC $(2.25 \mathrm{mg} / \mathrm{d})$ for patients are much lower than those of AZT and ddI (both $\sim 500 \mathrm{mg} / \mathrm{d})(39,40)$. We found that the ratios of intracellular ddCTP/dCTP were higher in R-PBM than in PHA-PBM. Moreover, the presence of ddC caused a substantial decrease in the dCTP pool size both in R-PBM and PHA-PBM ( Table II ). These profiles of intracellular anabolism of ddC may relate to the potent antiviral activity and side effects of ddC seen in vivo (39-41). It is likely that, as in the case of ddI, the antiviral activity of ddC may complement that of AZT and may bring about substantial antiviral activity than when each drug was administered alone. In fact, a simultaneous combination regi- men of AZT plus ddC has been shown to yield a preferable in vivo antiviral activity in patients with AIDS or ARC (41). However, it should be noted that because in our study only 10 $\mu \mathrm{M}\left[{ }^{3} \mathrm{H}\right] \mathrm{ddC}$ was used, more detailed studies using lower concentrations of $\mathrm{ddC}$ are required.

In conclusion, although $2^{\prime}, 3^{\prime}$-dideoxynucleoside analogues may have a common mechanism of anti-HIV activity, they have unequal anti-HIV activities and different anabolic phosphorylation profiles in the activated and resting PBM. Identification of these differences could benefit the development of strategies for anti-HIV chemotherapy, especially for combination chemotherapy.

\section{Acknowledgments}

We are grateful to Drs. Robert Wittes and John Driscoll for advice, Dr. Robert Yarchoan for helpful discussion, Dr. Seth Steinberg for statistic analysis, and Dr. Barry Anderson for critical reading of the manuscript.

\section{References}

1. Shirasaka, T., M. O'Brien, and H. Mitsuya. 1993. In vitro evaluation of experimental agents for anti-HIV activity. In Techniques of HIV Research. W. Strober, editor. Wiley Interscience, New York. In press.

2. Schinazi, R. F., J. P. Sommadossi, V. Saalmann, D. Cannon, M.-W. Xie G. C. Hart, G. A. Smith, and E. F. Hahn. 1990. Activity of 3'-azido-3'deoxythymidine nucleotide dimers in primary lymphocytes infected with human immunodeficiency virus type 1. Antimicrob. Agents Chemother. 34:1061-1067.

3. Mitsuya, H., R. Yarchoan, and S. Broder. 1990. Molecular targets for antiviral therapy against AIDS. Science (Wash. DC). 249:1533-1544.

4. De Clercq, E. 1992. HIV inhibitors targeted at the reverse transcriptase. AIDS Res. Hum. Retroviruses. 8:119-134.

5. Mayers, D. L., F. E. McCutchan, E. E. Sanders-Buel, L. I. Merritt, S. Dilworth, A. K. Fowler, C. A. Marks, N. M. Ruiz, D. D. Richman, C. R. Roberts, and D. S. Burke. 1992. Characterization of HIV isolates arising after prolonged zidovudine therapy. J. Acquired Immune Defic. Syndr. 5:749-759.

6. Shirasaka, T., R. Yarchoan, M. C. O'Brien, R. N. Husson, B. D. Anderson, E. Kojima, T. Shimada, S. Broder, and H. Mitsuya. 1993. Human immunodeficiency virus type 1 develops resistance more readily to azidothymidine than to dideoxycytidine or dideoxyinosine. Proc. Natl. Acad. Sci. USA. 90:562-566.

7. Zack, J. A., S. J. Arrigo, S. R. Weitsman, A. S. Go, A. Haislip, and I. S. Y. Chen. 1990. HIV-1 entry into quiescent primary lymphocytes: molecular analysis reveals a labile, latent viral structure. Cell. 61:213-222.

8. Bukrinsky, M. I., T. L. Stanwick, M. P. Dempsey, and M. Stevenson. 1992. Quiescent $\mathrm{T}$ lymphocytes as an inducible virus reservoir in HIV-1 infection. Science (Wash. DC). 254:423-427.

9. Zack, J. A., A. M. Haislip, P. Krogstad, and I. S. Y. Chen. 1992. Incompletely reverse-transcribed human immunodeficiency virus type 1 genome in quiescent cells can function as intermediates in the retroviral life cycle. J.Virol. $66: 1717-1725$.

10. Munch-Petersen, B., G. Tyrsted, and B. Dupont. 1973. The deoxyribonucleoside 5'-triphosphate (dATP and dTTP) pool in phytohemagglutinin-stimulated and non-stimulated human lymphocytes. Exp. Cell Res. 79:249-256.

11. Furman, P. A., J. A. Fyfe, M. H. St. Clair, K. Weinhold, J. L. Rideout, G. A. Freeman, S. N. Lehrman, D. P. Bolognesi, S. Broder, H. Mitsuya, and D. Barry. 1986. Mode of inhibition of the human T-cell lymphotropic virus III by 3'-azido-3'-deoxythymidine. Proc. Natl. Acad. Sci. USA. 83:8333-8337.

12. Cooney, D. A., M. Dalal, H. Mitsuya, J. B. McMahon, M. Nadkarni, J. Balzarini, S. Broder, and D. G. Johns. 1986. Initial studies on the cellular pharmacology of 2',3'-dideoxycytidine, an inhibitor of HTLV-III infectivity. Biochem. Pharmacol. 35:2065-2068.

13. Ahluwalia, G., D. A. Cooney, H. Mitsuya, A. Fridland, K. P. Flora, Z. Hao, M. Dalal, S. Broder, and D. G. Johns. 1987. Initial studies on the cellular pharmacology of $2^{\prime}, 3^{\prime}$-dideoxyinosine, an inhibitor of HIV infectivity. Biochem. Pharmacol. 36:3797-3800.

14. Johnson, M. A., and A. Fridland. 1989. Phosphorylation of 2',3'dideoxyinosine by cytosolic 5'-nucleotidase of human lymphoid cells. $\mathrm{Mol}$. Pharmacol. 36:291-295.

15. Yarchoan, R., H. Mitsuya, C. E. Myers, and S. Broder. 1989. Antiretroviral therapy of HIV infection: clinical pharmacology of 3'-azido-2',3'-dideoxythymidine (AZT) and related dideoxynucleosides. N. Engl. J. Med. 321:726-738.

16. Fischl, M. A., C. B. Parker, C. Pettinelli, M. Wulfsohn, M. S. Hirsch, A. C. Collier, D. Antoniskis, M. Ho, D. D. Richman, E. Fuchs, et al. 1990. Random- 
ized controlled trial of a reduced daily dose of zidovudine in patients with the acquired immunodeficiency syndrome. $N$. Engl. J. Med. 323:1009-1014.

17. Yarchoan, R., H. Mitsuya, R. V. Thomas, J. M. Pluda, N. R. Hartman. C. F. Perno, K. S. Marczyk, J.-P. Allain. D. G. Johns, and S. Broder. 1989. In vivo antiviral activity against HIV and favorable toxicity profile of the purine analogue 2',3'-dideoxyinosine (ddI). Science (Wash. DC). 245:412-415.

18. Cooley, T. P., L. M. Kunches, C. A. Saunders, J. K. Ritter, C. J. Perkins. C. McLaren, R. P. McCaffrey, and H. A. Liebman. 1990. Once-daily administration of $2^{\prime}, 3^{\prime}$-dideoxyinosine ( $\left.\mathrm{ddI}\right)$ in patients with the acquired immunodeficiency syndrome or AIDS-related complex. Results of a phase I trial. N. Engl. J. Med. 322:1340-1345.

19. Lambert, J. S., M. Seidlin, R. C. Reichman, C. S. Plank, M. Laverty, G. D. Morse, C. Knupp, C. McLaren, C. Pettinelli, F. T. Valentine, and R. Dolin. 1990 $2^{\prime}, 3^{\prime}$-Dideoxyinosine ( $\mathrm{ddI}$ ) in patients with the acquired immunodeficiency syndrome or AIDS-related complex. A phase I trial. N. Engl. J. Med. 322:13331340.

20. Dolin, R., J. S. Lambert, G. D. Morse, R. C. Reichman, C. S. Plank, J. Reid. C. Knupp. C. McLaren, and C. Pettinelli. 1990. 2',3'-Dideoxyinosine in patients with AIDS or AIDS-related complex. Rev. Infect. Dis. 12:S540-S551.

21. Klecker, R. W., J. M. Collins, R. Yarchoan, R. Thomas, J. F. Jenkins, S. Broder, and C. E. Myers. 1987. Plasma and cerebrospinal fluid pharmacokinetics of 3'-azido-3'-deoxythymidine: a novel pyrimidine analog with potential application for the treatment of patients with AIDS and related diseases. Clin. Pharmacol. \& Ther. 41:407-412.

22. Hartman, N. R., G. S. Ahluwalia, D. A. Cooney, H. Mitsuya, S. Kageyama. A. Fridland, S. Broder, and D. G. Johns. 1991. Inhibition of IMP dehydrogenase stimulate the phosphorylation of the anti-HIV nucleosides $2^{\prime}, 3^{\prime}$ dideoxyadenosine and 2',3'-dideoxyinosine. Mol. Pharmacol. 40:118-124.

23. Masood, R., G. S. Ahluwalia, D. A. Cooney, A. Fridland, V. E. Marquez. J. S. Driscoll, Z. Hao, H. Mitsuya, C. F. Perno, S. Broder, and D. G. Johns. 1990. 2'-Fluoro-2'.3'-dideoxyarabinosyl-adenine: a metabolically stable analogue of the antiretroviral agent 2',3'-dideoxy-adenosine. Mol. Pharmacol. 37:590-596

24. Sherman, P. A., and A. J. Fyfe. 1989. Enzymatic assay for deoxyribonucleoside triphosphates using synthetic oligonucleotides as template primers. Anal. Biochem. 180:222-226.

25. Cheng. Y. C., and M. Ostrander. 1976. Deoxythymidine kinase induced in HeLa TK-cells by herpes simplex virus type I and type II. J. Biol. Chem. 251:2605-2610.

26. Törnevik. Y.. B. Jacobsson. S. Britton, and S. Eriksson. 1991. Intracellular metabolism of 3 -azidothymidine in isolated human peripheral blood mononuclear cells. AIDS Res. Hum. Retroviruses. 7:751-759.

27. Perno, C. F., R. Yarchoan, D. A. Cooney, N. R. Hartman, D. S. A. Webb, Z. Hao, H. Mitsuya, D. G. Johns, and S. Broder. 1989. Replication of HIV in monocytes: granulocyte-macrophage colony stimulating factor (GM-CSF) potentiates viral production yet enhances the antiviral effect mediated by AZT and other dideoxynucleoside congeners of thymidine. J. Exp. Med. 169:933-951

28. Cheng, Y.-C., B. Domin, and L.-S. Lee. 1977. Purification and characterization of the cytoplasmic and mitochondrial isozymes derived from blast cells of acute myelocytic leukemia patients. Biochim. Biophys. Acta. 481:481-492.

29. Brockman, R. W., Y.-C. Cheng, F. M. Chabel, Jr., and J. A. Montgomery. 1980. Metabolism and chemotherapeutic activity of 9- $\beta$-D-arabinofuranosyl-2- fluoroadenine against murine leukemia L1210 and evidence for its phosphorylation by deoxycytidine kinase. Cancer Res. 40:3610-3615.

30. Cheng, N., and T. W. Traut. 1987. Uridine kinase: altered subunit size or enzyme expression as a function of cell type. growth stimulation. or mutagenesis. J. Cell. Biochem. 35:217-229.

31. Mitsuya. H., R. F. Jarrett. M. Matsukura, F. di Marzo Veronese, A. L. Devico, M. G. Sarngadharan. D. G. Johns. M. S. Reitz. and S. Broder. 1987. Long-term inhibition of HTLV-III/LAV DNA synthesis and RNA expression in T-cells protected by $2^{\prime}, 3^{\prime}$-dideoxynucleosides. Proc. Natl. Acad. Sci. US.A. 84:2033-2037.

32. Huang, P.. D. Farquhar, and W. Plunkett. 1990. Selective action of 3'azido-3'-deoxythymidine 5'-triphosphate on viral reverse transcriptase and human DNA polymerase. J. Biol. Chem. 265:11914-11918.

33. Varmus. H. E., T. Padgett. S. Deasley. G. Simon, and J. M. Bishop. 1977. Cellular functions are required for the synthesis and integration of avian sarcoma virus-specific DNA. Cell. 11:307-319.

34. Harel, J., E. Rassart, and P. Jolicoeur. 1981. Cell cycle dependence of synthesis of unintegrated viral DNA in mouse cells newly infected with murine leukemia virus. Virology. 110:202-207.

35. Aoki. S. R. Yarchoan. R. V. Thomas, J. M. Pluda K. Marczyk. S. Broder and H. Mitsuya. 1990. Quantitative analysis of HIV-1 DNA in peripheral blood mononuclear cells from patients with AIDS or ARC: decrease of viral DNA content following treatment with dideoxyinosine (ddI ). AIDS Res. Hum. Retroviruses. 6:1331-1339.

36. McElrath. M. J., R. M. Steinman, and Z. A. Cohn. 1991. Latent HIV-I infection in enriched populations of blood monocytes and $\mathrm{T}$ cells from seropositive patients. J. Clin. Invest. 87:27-30.

37. Clark. A. G., M. Holodniy, D. H. Schwartz, D. A. Katzenstein, and T. C. Merigan. 1992. Decrease in HIV provirus in peripheral blood mononuclear cells during zidovudine and human rIL-2 administration. J. Acquired Immune Defic Syndr. 5:52-59.

38. Yarchoan, R.. J. A. Lietzau. O. Brawley, B.-Y. Ngwyen, J. M. Pluda. K. M. Wyvill, and S. Broder. 1992. Therapy of AIDS or symptomatic HIV infection with simultaneous or alternating regimens of AZT and ddI. Proceedings of VIII Int'l Conference on AIDS/III STD World Congress, Amsterdam. July 1924. MoB 0054. (Abstr.)

39. Yarchoan. R.. C.-F. Perno, R. V. Thomas, R. W. Klecker, J. P. Allain. J. Wills. N. McAtee. M. A. Fischl, R. Dubinski, M. C. Mcneely, et al. 1988. Administration of $2^{\prime}, 3^{\prime}$-dideoxycytidine to patients with severe human immunodeficiency virus infection as a single agent in an alternating regimen with $3^{\prime}$-azido-2', $3^{\prime}$ dideoxythymidine (AZT). Lancet. i:76-81.

40. Merigan, T. C., G. Skowron. S. A. Bozzette, D. Richman, R. Uttamchandani, M. Fischl. R. Schooley, M. Hirsch. W. Soo, C. Pettinelli, et al. 1989. Circulating p24 antigen levels and responses to dideoxycytidine in human immunodeficiency virus (HIV) infections. A phase I and II study. Ann. Intern. Med. 110:189194.

41. Meng, T.-C., M. A. Fischl, A. M. Boota, S. A. Spector. D. Bennett, Y. Bassiakos, S. Lai. B. Wright, and D. D. Richman. 1992. Combination therapy with zidovudine and dideoxycytidine in patients with advanced human immunodeficiency virus infection. Ann. Intern. Med. 116:13-20. 